\title{
Complications, and Requirement of Opioid Use after Rib Fractures, an Analysis of 1074 Patients
}

\section{Kot Kırıkları Sonrası Komplikasyonlar ve Opioid Kullanımı Gerekliliği, 1074 Hastanın Analizi}

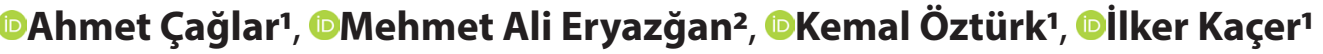 \\ 'Aksaray University Training and Research Hospital, Department of Emergency Medicine, Aksaray, Turkey \\ ${ }^{2}$ Aksaray University School of Medicine, Department of Thoracic Surgery, Aksaray, Turkey
}

\begin{abstract}
Aim: This study was aimed to determine the risk factors, associated complications, opioid requirements, and mortality rates of rib fractures.

Material and Method: Patients with rib fractures who were admitted to the emergency department between January 1, 2016, and December 31, 2020, were retrospectively analyzed. Patients' demographic data, rib fracture characteristics, trauma mechanism, associated complications, length of stay in the hospital, and inhospital mortality were recorded.

Results: A total of 1074 patients were included in the study. Most of the patients were male $(n=748,69.6 \%)$ and the mean age was $53.89 \pm 15.31$ years. The mean number of fractured ribs was $3.65 \pm 2.06$. All patients with diaphragm laceration, atelectasis, pneumonia, ARDS, pneumomediastinum, lung herniation, flail chest, and empyema had six or more rib fractures. Comparison of died and survived patients showed statistically significant difference for age, gender, side of rib fracture, number of fractured ribs, and accompanying another organ injury. A moderate-strong correlation was found between the number of fractured ribs and pneumothorax, hemothorax, chest tube, opioid use, and length of stay in the hospital.
\end{abstract}

Conclusion: Increased number of fractured ribs were associated with increased complications, opioid use, and length of stay in the hospital. The mortality rate was $8.8 \%$ in patients with 6 or more fractures. In-vehicle traffic accidents were the most common mechanism. Many of the rib fractures can be prevented if the measures are improved.

Keywords: Flail chest, hemothorax, opioid use, pneumothorax, rib fracture
Öz

Amaç: Bu çalışma, kaburga kırıklarının risk faktörlerini, ilişkili komplikasyonları, opioid gereksinimini ve ölüm oranların değerlendirmeyi amaçlamaktadır.

Gereç ve Yöntem: 1 Ocak 2016 ile 30 Eylül 2020 tarihleri arasında acil servise başvuran ve kot kırığı olan hastalar retrospektif olarak incelendi. Hastaların demografik verileri, kot kırı̆ı̆ın özellikleri, travma mekanizması, ilişkili komplikasyonlar, hastanede kalış süreleri ve hastane içi mortalite kaydedildi.

Bulgular: Çalışmaya toplam 1074 hasta dahil edildi. Hastaların çoğu erkekti ( $n=748, \% 69.6)$ ve ortalama yaş 53.89 15.31 yıldı. Ortalama kırık kot sayısı $3.65 \pm 2.06$ idi. Diyafram yırtığı, atelektazi, pnömoni, ARDS, pnömomediasten, akciğer herniasyonu, yelken göğüs ve ampiyemi olan tüm hastalarda altı veya daha fazla kot kırığı vardı. Ölen ve hayatta kalan hastaların karşılaştırılmasında, yaş, cinsiyet, kaburga kırığı tarafı, kırık kaburga sayısı ve eşlik eden başka bir organ yaralanması açısından istatistiksel olarak anlamlı farklıık mevcuttu. Kırık kot sayısı ile pnömotoraks, hemotoraks, göğüs tüpü, opioid kullanımı ve hastanede kalış süresi arasında orta-güçlü bir korelasyon bulundu.

Sonuç: Kırık kot sayısının artması, artan komplikasyonlar, opioid kullanımı ve hastanede kalış süresi ile ilişkiliydi. Altı ve daha fazla kıı̆ı̆ı olan hastalarda ölüm oranı \%8.8 idi. Araç içi trafik kazaları en yaygın mekanizmaydı. Tedbirler iyileştirilirse kot kırıklarının büyük bir kısmı önlenebilir.

Anahtar Kelimeler: Hemotoraks, kaburga kırı̆̆ı, opioid kullanımı, pnömotoraks, yelken göğüs 


\section{INTRODUCTION}

Rib fractures are the most common form of blunt thoracic injuries, constituting approximately $10 \%$ of all trauma patients; mortality rates are over $10 \% \cdot{ }^{[1-3]}$ The most common mechanisms of traumatic thoracic injury are motor vehicle accidents, falls, and crush injuries. ${ }^{[4]}$ Rib fractures can also occur due to repetitive stress and microtrauma, or severe cough. ${ }^{[5]}$ Rib fractures are an important indicator of trauma severity. The rate of morbidity and mortality increase in line with the increase in the number of fractured ribs. ${ }^{[6]}$

Ribs can be divided into three regions, based on the severity of trauma in the injury and the associated complications. The upper region includes the first four ribs, the lower region includes the last three ribs, and the middle region includes the five ribs numbered 5 to $9{ }^{[7-9]}$ Upper region fractures are often resulted from high energy trauma and are associated with vascular structures or brachial plexus injury. ${ }^{[7]}$ Complications such as pulmonary laceration, pulmonary contusion, extrapleural hematoma, hemothorax, and pneumothorax are more common in the fractures of the middle rib region. ${ }^{[8]}$ Rib fractures in the lower region have been associated with liver and spleen injuries. ${ }^{[9]}$

In this study, we aimed to determine the risk factors, associated complications, opioid requirements, and mortality rates of rib fractures in our region.

\section{MATERIAL AND METHOD}

This retrospective study was carried out in the emergency department of a regional academic hospital. The study was conducted in compliance with the principles of the Declaration of Helsinki and approved by the local ethical committee (2020/09-30).

\section{Study Design, Setting, and Patient Selection}

The medical records of patients who were admitted to the emergency department and diagnosed with rib fractures via X-ray or computed tomography between January 1, 2016, and December 31, 2020, were retrospectively analyzed. Patients with missing data, repeated admissions and younger than 18 years old were excluded from the study.

Patients' demographic data, rib fracture characteristics, trauma mechanism, associated complications, length of stay in the hospital, and in-hospital mortality were recorded.

\section{Statistical Analysis}

Data were analyzed using SPSS version 22.0 (SPSS Inc, Chicago, IL, USA). Visual (histogram and probability graphs) and analytical method (Kolmogorov-Smirnov test) were used to determine distribution normality. Descriptive analyzes were expressed as mean \pm standard deviation (SD) for normally distributed variables and as median and interquartile range (IQR) for nonnormally distributed variables. Categorical data were expressed as $\mathrm{n}(\%)$. Survival and death patients were compared using chisquare or Fischer's exact test for categorical variables, using
Student's t-test for normally distributed variable (age), and using the Mann-Whitney $U$ test for non-normally distributed variable (number of fractured ribs). Spearman's Correlation Analysis was used to test the relations between the number of rib fractures and related complications, and clinical outcomes. A p value of $<0.05$ was considered as statistically significant.

\section{RESULTS}

A total of 1158 patients were found to be eligible for this study, and 84 of those patients were excluded because of missing data and repeated admissions. Finally, a total of 1074 patients were included. Most of the patients were male $(n=748,69.6 \%)$ and the mean age was $53.89 \pm 15.31$ (ranging between 18 and 94) years.

The most common mechanism of injury was in-vehicle traffic accident ( $n=508,47.3 \%)$, followed by falls from ground-level $(n=220,20.5 \%)$, and non-vehicle traffic accident $(n=140,13 \%)$. It was observed that the sixth rib fractured the most $(n=516$, $48 \%)$, and the twelfth rib the least $(n=80,7.4 \%)$. Sternum fracture was observed in $140(13 \%)$ patients. The chest tube was applied to 160 (14.9\%) patients. A majority of the patients $(n=582,54.2 \%)$ were admitted to the thoracic surgery clinic. The mortality rate was $4.5 \%(n=48)$. Injury characteristics of the patients are summarized in Table 1.

288 (26.8\%) patients were diagnosed with pneumothorax and $378(35.2 \%)$ patients were diagnosed with hemothorax. Acute respiratory distress syndrome (ARDS) was developed in $18(1.7 \%)$ patients. Liver and spleen lacerations were observed in $46(4.3 \%)$ and 34 (3.2\%) patients, respectively. Nine (0.8\%) of patients had a cardiac injury, and all of these patients had sternum fractures. As a result of the first rib fracture, subclavian artery injury was observed in one patient, and brachial plexus injury was observed in one patient. Complications of rib fractures are shown in Table 2.

Considering accompanying injuries among dead patients, $8(16.7 \%)$ patients had a head injury, $4(8.3 \%)$ patients had a vertebrae injury, 8 (16.7\%) patients had an extremity injury, 22 (45.8\%) patients had an abdominal injury, and $12(25 \%)$ patients had a pelvic injury. Most of the accompanying injuries $(n=21$, $70 \%$ ) presented with the left side rib fractures. Comparison of died and survived patients showed statistically significant difference for age, gender, side of rib fracture, number of fractured ribs, and accompanying another organ injury. There was not a statistically significant difference in length of stay in hospital (Table 3).

The mean number of fractured ribs was $3.65 \pm 2.06$. All patients with diaphragm laceration, atelectasis, pneumonia, ARDS, pneumomediastinum, lung herniation, flail chest, and empyema had six or more rib fractures. Comparison of patients according to the number of rib fractures was summarized in Table 4. A moderate-strong correlation was found between the number of fractured ribs and pneumothorax, hemothorax, chest tube, opioid use, and length of stay in hospital (Table 5). 


\section{Table 1. Injury characteristics of rib fractures}

\section{Injury mechanism, $\mathbf{n}(\%)$}

Falls from ground-level

Falls from a height

In vehicle traffic accident

Non vehicle traffic accident

Crushing with a foreign body

Assault

Post-cpr

Stress fractures

\section{Rib number, $\mathbf{n}$ (\%)}

1

2

3

5

6

7

8

10

11

12

Side of fracture, $\mathbf{n}(\%)$

$$
\text { Left }
$$

Right

Number of rib fractures, mean \pm SD

$460(42.8)$

$504(46.9)$

$510(47.5)$

$466(43.4)$

$370(34.5)$

$270(25.1)$

$240(22.3)$

$164(15.3)$

$80(7.4)$

\section{Number of rib fractures, $\mathbf{n}(\%)$}

$1-2$

3-5

$\geq 6$

Segment of rib fractures, $\mathbf{n}(\%)$

Upper segment

Middle segment

Lower segment

$3.65 \pm 2$

$334(31.1)$

$558(52)$

$182(16.9)$

$584(54.4)$

$782(72.8)$

$268(25)$

$\begin{array}{ll}\text { Accompanying other fractures, } \mathbf{n} \text { (\%) } & 140(13) \\ \text { Sternum } & 42(3.9) \\ \text { Clavicula } & 33(3.1)\end{array}$

Opioid use, $\mathbf{n}(\%)$

None

Once a day

Twice a day

Three or more in a day

Other accompanying traumas, $\mathbf{n}(\%)$

Head injury

Extremity injury

Abdominal injury

Vertebrae injury

Pelvis injury

$274(25.5)$

$286(26.6)$

408 (38)

106 (9.9)

$380(35.4)$

$172(16)$

$160(14.9)$

$96(8.9)$

$108(10.1)$

$16(1.5)$

Length of stay in hospital, median (min-max)

$4(1-32)$

Prognosis, n (\%)

Discharged from emergency department $183(17)$

Admitted to thoracic surgery clinic $582(54.2)$

Admitted to intensive care unit 261 (24.3)

Exitus

\section{DISCUSSION}

In this study, we evaluated the clinical features of patients with rib fractures admitted to the emergency department. Our results confirmed that the increased number of rib fractures was associated with increased complications, opioid use, and length of stay in the hospital. Increased age, female gender, left side rib fractures, and accompanying other organ traumas were associated with increased mortality.

\section{Table 2. Complications associated with rib fractures}

Pneumothorax

288 (26.8)

Hemothorax

$378(35.2)$

Pulmonary contusion

$506(47.1)$

Subcutaneous emphysema

$21(2)$

Pneumomediastinum

28 (2.6)

Lung herniation

$3(0.3)$

Chest tube

$160(14.9)$

Flail chest

$5(0.5)$

Pneumonia

25 (2.3)

Acute respiratory distress syndrome

18 (1.7)

Atelectasis

$49(4.6)$

Empyema

$9(0.8)$

Heart injury

$9(0.8)$

Subclavian artery injury

$1(0.1)$

Brachial plexus injury

$1(0.1)$

Diaphragm laceration

$8(0.7)$

Liver laceration

46 (4.3)

Spleen laceration

34 (3.2)

Kidney laceration

28 (2.6)

Data were presented as $\mathrm{n}(\%)$

Tablo 3. Comparison of survival and death patients

\begin{tabular}{|c|c|c|c|}
\hline & $\begin{array}{l}\text { Survival } \\
(n=1026)\end{array}$ & $\begin{array}{l}\text { Death } \\
(n=48)\end{array}$ & $\begin{array}{c}P \\
\text { value }\end{array}$ \\
\hline Age (years), mean \pm SD & $53.65 \pm 15.3$ & $59.02 \pm 12.5$ & 0.017 \\
\hline $\begin{array}{l}\text { Gender, } \mathbf{n}(\%) \\
\text { Male } \\
\text { Female }\end{array}$ & $\begin{array}{l}722(70.4) \\
304(29.6)\end{array}$ & $\begin{array}{l}26(54.2) \\
22(45.8)\end{array}$ & 0.017 \\
\hline $\begin{array}{l}\text { Side of fracture, } \mathbf{n}(\%) \\
\text { Right } \\
\text { Left }\end{array}$ & $\begin{array}{l}583(56.8) \\
443(43.2)\end{array}$ & $\begin{array}{l}17(35.4) \\
31(64.6)\end{array}$ & 0.004 \\
\hline Number of rib fractures, mean $\pm S D$ & $3.57 \pm 2$ & $5.19 \pm 1.7$ & 0.000 \\
\hline $\begin{array}{l}\text { Other accompanying traumas, } \mathbf{n}(\%) \\
\text { No } \\
\text { Yes }\end{array}$ & $\begin{array}{l}676(65.9) \\
350(34.1)\end{array}$ & $\begin{array}{l}18(37.5) \\
30(62.5)\end{array}$ & 0.000 \\
\hline $\begin{array}{l}\text { Length of stay in hospital, median } \\
\text { (IQR) }\end{array}$ & $4(4)$ & $3(2)$ & 0.145 \\
\hline
\end{tabular}

Table 4. Comparison of patients according to the number of rib fractures.

Number of fractured

ribs

1-2 3-4-5 $\geq 6$

\begin{tabular}{lllll}
\hline Pneumothorax & $44(13.2)$ & $108(19.4)$ & $136(74.7)$ & 0.000
\end{tabular}

$(\mathbf{n}=\mathbf{5 5 2})$

$(\mathrm{n}=182)$

P value

Hemothorax

34 (10.2)

$216(38.7)$

$128(70.3)$

0.000

Lung contusion

84 (25.1)

$284(50.9)$

138 (75.8)

8 (2.4)

40 (7.2)

$112(61.5)$

0.000

Liver laceration

9 (2.7)

25 (4.5)

12 (6.6)

0.000

Spleen laceration

9 (2.7)

17 (3)

8 (4.4)

0.107

Mortality

$3(0.9)$

$16(8.8)$

0.558

Data were presented as $\mathrm{n}(\%)$

Table 5. Correlations between number of rib fractures and complications, and clinical outcomes

Number of rib fractures - pneumothorax

Number of rib fractures - hemothorax

Number of rib fractures - chest tube

Number of rib fractures - liver laceration

Number of rib fractures - spleen laceration

Correlation coefficien

P

0.406

0.398

0.450

0.072

0.055

0.793 value

Number of rib fractures - opioid use

0.524

Number of rib fractures - length of stay in hospital $<0.001$ $<0.001$ $<0.05$ 0.072 $<0.001$ $<0.001$ 
Conservative treatment is usually sufficient for patients with uncomplicated single rib fractures; however, multiple rib fractures with complications are an important indicator of morbidity and mortality. ${ }^{[6]}$ In a large retrospective cohort conducted at level 1 trauma center, mortality rates were $5 \%$ in patients with one or two rib fractures, $15 \%$ in patients with three to five rib fractures, and $34 \%$ in patients with six or more rib fractures. ${ }^{[10]}$ Flagel et al. ${ }^{[11]}$ reported that every additional rib fracture increases the mortality rate. In addition, six or more rib fractures were an independent risk factor for mortality in trauma patients. The results of the present study indicate a linear relationship between the number of fractured ribs and length of stay in the hospital, and prognosis, similar to the literature. However, the mortality rates were lower than the literature. This may be due to trauma mechanisms in our region (Central Anatolia Region). There were 220 (20.5\%) patients who fell down from the ground level, and none of them died.

Pulmonary complications are important causes of morbidity and mortality in patients with rib fractures. ${ }^{[6]} \mathrm{A}$ retrospective analysis of 64,750 patients with rib fractures showed that $13 \%$ of patients experienced one or more complications including pneumothorax, pneumonia, ARDS, pulmonary embolism, and empyema. ${ }^{[1]]}$ Liman et al. ${ }^{[12]}$ demonstrated that $81 \%$ of patients with two or more rib fractures had pneumothorax or hemothorax. In this study, pneumothorax, hemothorax, and contusion rates were $26.8 \%, 35.2 \%$, and $47.1 \%$ respectively. Acute respiratory distress syndrome was presented in $18(1.7 \%)$ patients, and these patients needed admission to the ICU. These rates are in line with the literature. In addition, each additional rib fracture increased the pulmonary complications, and related mortality.

Associated organ injury often correlated with the fractured ribs' anatomical location. ${ }^{[13,14]}$ Lower rib fractures are related with upper abdominal solid organ injury. ${ }^{[9]}$ The presence of left lower rib fractures is considered as an indicator of further radiographic evaluation to rule out the splenic injury. ${ }^{[15]}$ The fracture of the first or second ribs is an important indicator of severe trauma.[6,7] The presence of upper rib fractures is considered as an indicator of further radiographic evaluation to rule out intrathoracic major blood vessels injuries. ${ }^{[7]}$ In the present study, liver, spleen and kidney laceration rates were $4.3 \%, 3.2 \%$, and $2.6 \%$ respectively. In addition, left side fractures were more common among dead patients. These fractures may have resulted in a spleen laceration and so life-threatening bleeding. We did not observe any complication related to upper rib fractures except for two patients (one patient with subclavian artery injury and one patient with brachial plexus injury). There were 9 patients with heart injury, all of them had sternum fractures, and the trauma mechanisms were in-vehicle traffic accidents. The seat belt usage habits in our region should be reviewed and all drivers should be regularly trained in specific periods.
The flail chest is the most important life-threatening complication of rib fractures, with high mortality rates. Patients with flail chest often require admission to ICU and mechanical ventilation. ${ }^{[16]}$ An another life-threatening complication of rib fractures is lung herniation, and requires nonemergent thoracotomy ${ }_{.}^{[6]}$ In the present study, we observed 5 patients with flail chest and 3 patients with lung herniation. All patients with flail chest were intubated, 3 of them needed surgical fixation, and one of operated patients were died after surgery. Thoracotomy was performed in all three patients with lung herniation. One of them died after surgery because of accompanied subarachnoid hemorrhage.

Patients who are 65 years old and over have higher rates of pneumonia and associated deaths after rib fractures. ${ }^{[17,18]}$ Ziegler et al. ${ }^{[1]}$ reported that mortality rates were higher in the elderly even though the injury severity score was lower. The reasons for these high mortality rates may be the increasing incidence of comorbid diseases and osteopenic changes with aging. ${ }^{[19]}$ In this study, the mean age of survived patients was significantly lower than dead patients, however there was not such a relationship in pulmonary complications.

Pain is often the predominant symptom of a rib fracture. ${ }^{[6]}$ Pain management in patients with rib fractures is important because severe pain may cause shallow breathing, impaired coughing, leading to atelectasis, and finally respiratory failure..$^{[18,21]}$ Early parenteral nonsteroidal anti-inflammatory drug administration may reduce opioid requirement, the incidence of pneumonia, number of ventilator days, length of stay in the hospital, and length of stay in the ICU. ${ }^{[22,23]}$ Opioid requirement increases with the number of fractured ribs. ${ }^{[24]} \mathrm{A}$ multicenter analysis of rib fractures showed that patients-controlled pain management may decrease the mortality rates. ${ }^{[25]}$ In our study, 274 (25.5\%) patients treated with nonsteroidal anti-inflammatory drugs, and did not require opioids. Increased number of fractured ribs were resulted in increased opioid requirement.

Although the present study's strength is its large sample size, it is a retrospective and single-center study and has some limitations. First, we evaluated in-hospital mortality as the primary endpoint of the study. However, some of complications can affect mortality even after the hospital period. Second, data of injury severity score was not available, and the impact of ISS on mortality could not be evaluated. Furthermore, the lack of detailed data limited the analysis about chronic diseases that can effect mortality after rib fractures. There is a need for multicenter, prospective studies in order to better understand rib fractures and related complications.

\section{CONCLUSION}

Increased number of fractured ribs were associated with increased complications, opioid use, and length of stay in the hospital. The mortlality rate was $8.8 \%$ in patients with 6 or more factures. In-vehicle traffic accidents were the most common mechanism. Many of the rib fractures can be prevented if the measures are improve. 


\section{ETHICAL DECLARATIONS}

Ethics Committee Approval: The study was conducted in compliance with the Declaration of Helsinki and approval by Aksaray University School of Medicine, Aksaray Training and Research Hospital Scientific Research Evaluation Committee (2020/09-30).

Informed Consent: Because the study was designed retrospectively, no written informed consent form was obtained from patients

Referee Evaluation Process: Externally peer-reviewed.

Conflict of Interest Statement: The author(s) declared no potential conflicts of interest with respect to the research, authorship, and/or publication of this article.

Financial Disclosure: The authors declared that this study has received no financial support.

\section{REFERENCES}

1. Ziegler DW, Agarwal NN. The morbidity and mortality of rib fractures. J Trauma 1994;37(6):975-9.

2. Jensen CD, Stark JT, Jacobson LL, et al. Improved Outcomes Associated with the Liberal Use of Thoracic Epidural Analgesia in Patients with Rib Fractures. Pain Med 2017;18(9):1787-94.

3. Weiser TG. Overview of thoracic trauma. In: Merck Manual Professional Version. Kenilworth, New Jersey: Merck; 2014.

4. Pines G, Gotler Y, Lazar LO, Lin G. Clinical significance of rib fractures' anatomical patterns. Injury 2020;51(8):1812-6.

5. Katrancioglu O, Akkas Y, Arslan S, Sahin E. Spontaneous rib fractures. Asian Cardiovasc Thorac Ann 2015;23(6):701-3.

6. Talbot BS, Gange CP Jr, Chaturvedi A, Klionsky N, Hobbs SK, Chaturvedi A. Traumatic Rib Injury: Patterns, Imaging Pitfalls, Complications, and Treatment. Radiographics 2017;37(2):628-51.

7. Sammy IA, Chatha $H$, Lecky $F$, et al. Are first rib fractures a marker for other life-threatening injuries in patients with major trauma? A cohort study of patients on the UK Trauma Audit and Research Network database. Emerg Med J 2017;34(4):205-11.

8. Park S. Clinical Analysis for the Correlation of Intra-abdominal Organ Injury in the Patients with Rib Fracture. Korean J Thorac Cardiovasc Surg 2012;45(4):246-50.

9. Al-Hassani A, Abdulrahman $\mathrm{H}$, Afifi $\mathrm{I}$, et al. Rib fracture patterns predict thoracic chest wall and abdominal solid organ injury. Am Surg 2010;76(8):888-91.

10. Sharma OP, Oswanski MF, Jolly S, Lauer SK, Dressel R, Stombaugh HA. Perils of rib fractures. Am Surg 2008;74(4):310-4.

11. Flagel BT, Luchette FA, Reed RL, et al. Half-a-dozen ribs: the breakpoint for mortality. Surgery 2005t;138(4):717-23.

12. Liman ST, Kuzucu A, Tastepe Al, Ulasan GN, Topcu S. Chest injury due to blunt trauma. Eur J Cardiothorac Surg 2003;23(3):374-8.

13. Ivey KM, White CE, Wallum TE, et al. Thoracic injuries in US combat casualties: a 10-year review of Operation Enduring Freedom and Iraqi Freedom. J Trauma Acute Care Surg 2012;73:S514-9.

14. Shweiki E, Klena J, Wood GC, Indeck M. Assessing the true risk of abdominal solid organ injury in hospitalized rib fracture patients. J Trauma 2001;50(4):684-8.

15. Holmes JF, Ngyuen H, Jacoby RC, McGahan JP, Bozorgchami H, Wisner $\mathrm{DH}$. Do all patients with left costal margin injuries require radiographic evaluation for intraabdominal injury? Ann Emerg Med 2005;46(3):232-6.

16. Dehghan N, de Mestral C, McKee MD, Schemitsch EH, Nathens A. Flail chest injuries: a review of outcomes and treatment practices from the
National Trauma Data Bank. J Trauma Acute Care Surg 2014;76(2):462-8.

17. Bulger EM, Arneson MA, Mock CN, Jurkovich GJ. Rib fractures in the elderly. J Trauma. 2000;48(6):1040-6.

18. Bergeron E, Lavoie A, Clas D, et al. Elderly trauma patients with rib fractures are at greater risk of death and pneumonia. J Trauma 2003;54(3):478-85.

19. Abdulrahman H, Afifi I, El-Menyar A, et al. Clinical outcomes of multiple rib fractures: does age matter? Eur J Trauma Emerg Surg 2013;39(6):605-11.

20. Crandall J, Kent R, Patrie J, Fertile J, Martin P. Rib fracture patterns and radiologic detection--a restraint-based comparison. Annu Proc Assoc Adv Automot Med 2000;44:235-59.

21. Bayouth L, Safcsak K, Cheatham ML, Smith CP, Birrer KL, Promes JT. Early intravenous ibuprofen decreases narcotic requirement and length of stay after traumatic rib fracture. Am Surg 2013;79(11):1207-12.

22. Yang Y, Young JB, Schermer CR, Utter GH. Use of ketorolac is associated with decreased pneumonia following rib fractures. Am J Surg 2014;207(4):566-72.

23. Dalton MK, Chaudhary MA, Andriotti T, et al. Patterns and predictors of opioid prescribing and use after rib fractures. Surgery 2020;168(4):684-9.

24. Harrington DT, Phillips B, Machan J, et al. Factors associated with survival following blunt chest trauma in older patients: results from a large regional trauma cooperative. Arch Surg 2010;145(5):432-7. 